\title{
Variability studies in Intra specific crosses of Indian mustard [Brassica juncea (L.) Czern and Coss.] genotypes.
}

\author{
G. J. Synrem ${ }^{* 1}$, N. R. Rangare ${ }^{2}$, I. Myrthong ${ }^{3}$ and D.M. Bahadure ${ }^{4}$ \\ ${ }^{*}$ (Ph. D Scholar Dept. of Genetics and Plant Breeding, SHIATS, Allahabad, India) \\ ${ }^{2}$ (Assistant Prof. Dept. of GPB, SHIATS, Allahabad, India) \\ ${ }^{3}$ (Ph. D Scholar Dept. of Environmental Science, SHIATS, Allahabad, India) \\ ${ }^{4}$ (Ph. D Scholar Dept. of Genetics and Plant Breeding, SHIATS, Allahabad, India)
}

\begin{abstract}
The genetic variability in intra specific crosses of Indian mustard Brassica juncea (L.) Czern and Coss. genotypes were evaluated during rabi 2009-10 to study the genetic variability, heritability and genetic advance as percentage of mean for nine quantitative characters viz. plant height (cm), number of siliquae per main branch, number of primary branches per plant, number of secondary branches per plant, length of siliquae (cm), number of seeds per siliqua and seed yield per plant (g), days to 50\% flowering and days to maturity. Analysis of variance showed significant differences among the crosses for all characters under study except for length of siliqua. Maximum genotypic coefficient of variation $(G C V)$ and phenotypic coefficient of variation $(P C V)$ was exhibited by number of secondary branches per plant followed by seed yield per plant and number of primary branches per plant. High estimates of heritability coupled with high genetic advance as per cent of mean was observed for number of secondary branches per plant followed by seed yield per plant and number of primary branches per plant.
\end{abstract}

Key words: Brassica juncea (L.), GCV, genetic advance, heritability Indian mustard, PCV, and variability.

\section{Introduction}

The large spectrum of genetic variability in a population depends on the amount of the genetic variability among genotypes and offer better scope for selection. The magnitude of heritable variation in the traits studied has immense value in understanding the potential of the genotype for further breeding programme. Variability for economic traits must exist in the working germplasm for profitable exploitation following recombination breeding and selection. Genetic diversity plays an important role in plant breeding because hybrid between lines of diverse origin generally display a great heterosis than those between closely related strains (Singh, 1983) which permits to select the genetically divergent plants to obtain the desirable recombination of the segregating generation. High magnitude of variability in a population provides the opportunity for selection to evolve a variety having desirable characters. Coefficient of variation is helpful in exposing and understanding the clear picture of existing variability within the population. Heritability coupled with genetic advance would be more useful tool in predicting the resultant effect in selection of the best genotypes for seed yield and its attributing traits. With the above background information the present investigation was undertaken to study the genetic parameters among the various crosses of Indian mustard.

\section{Materials and Methods}

The present experiment was conducted during rabi 2009-10 to evaluate 48 intra specific crosses of Indian mustard Brassica juncea (L.), generated by crossing between twelve lines $\left(\mathrm{L}_{1}-\mathrm{GM}-1, \mathrm{~L}_{2}-\mathrm{RL}-1359, \mathrm{~L}_{3}-\mathrm{KRISHNA}\right.$,

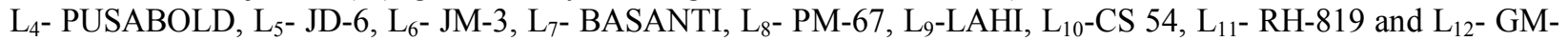
2) with four testers ( $T_{1}$ - DURGAMANI, $T_{2}$ - VARUNA, $T_{3}$ - LAXMI and $T_{4}-\mathrm{JM}-2$ ) during rabi 2008-09 in $\mathrm{L} \times \mathrm{T}$ mating design (Kempthrone, 1957). The experiment was conducted at the Field Experimentation Centre, Department of Genetics and Plant Breeding, SHIATS, Allahabad in Randomized Block Design (RBD) with two replications. Row to row and plant to plant distance was kept at 45 and $10 \mathrm{~cm}$, respectively. The recommended fertilizer dose was followed for $\mathrm{N}: \mathrm{P}_{2} \mathrm{O}_{5}: \mathrm{K}_{2} \mathrm{O} @$ @ 80:40:40, kg/ha. The recommended agricultural package of practices was followed to raise a healthy crop. Five randomly selected plants were selected to record the data for seven quantitative characters viz. plant height $(\mathrm{cm})$, number of siliquae per main branch, number of primary branches per plant, number of secondary branches per plant, length of siliquae $(\mathrm{cm})$, number of seeds per siliqua and seed yield per plant (g) while the two characters viz., days to $50 \%$ flowering and days to maturity were recorded on 
Variability studies in Intra specific crosses of Indian mustard (Brassica juncea (L.) Czern and Coss.)

plot basis. Test of significance for each character were analyzed as per methodology advocated by Panse and Sukhatme (1967). Genotypic coefficient of variation (GCV) and phenotypic coefficient of variation (PCV) were calculated by the formula given by Burton (1952), heritability in broad sense $\left(h^{2}\right)$ by Burton and De Vane (1953) and genetic advance i.e. the expected genetic gain were calculated by using the procedure proposed by Johnson et al. (1955).

\section{Results and Discussion}

The analysis of variance (Table 1) was highly significant among the divergent genotypes for all the nine traits under study, which revealed the presence of considerable variability among the forty eight intra specific crosses of Indian mustard (Brassica juncea L.) for the nine quantitative characters studied. The perusal of data revealed that variance due to crosses was highly significant for all the characters studied except for length of siliquae $(\mathrm{cm})$. This suggested that adequate scope is available for selection of superior genotypes aimed at enhancing genetic yield potential of Brassica juncea (L.). High magnitude of variability has been earlier reported in Indian mustard germplasm and varities for various characters like days to $50 \%$ flowering, days to maturity, plant height (cm), total siliquae/plant and seed yield/plant (g) (Kumar and Misra 2007). The reason for high magnitude of variability in the present study may be due the fact that the genotypes selected were developed in different breeding programmes representing different agro-climatic conditions of the country.

Genetic parameters (Table 2) were studied to examine genetic worth of yield and yield contributing traits, based on genetic variability estimates viz., phenotypic coefficient of variation (PCV), genotypic coefficient of variation (GCV), heritability $\left(\mathrm{h}^{2}\right)$, and genetic advance as percent of mean (GAM). Maximum genotypic and phenotypic variances was exhibited by plant height (100.88 and 104.23) followed by number of siliquae per main branch (20.59 and 22.51). The results of Coefficient of variation indicated that the estimates of phenotypic coefficient of variation (PCV) were higher than the corresponding genotypic coefficient of variation (GCV) for days to $50 \%$ flowering, plant height, number of siliquae per main branch, primary branches per plant, secondary branches per plant, length of siliquae, number of seeds per siliquae, days to maturity and seed yield per plant. Similar findings pertaining to presence of high genetic variability were reported for different traits including seed yield/plant (Singh 2004).

Higher estimates of phenotypic coefficient of variation (PCV) than genotypic coefficient of variation (GCV) for all the traits reflected the influence of environmental factor on these traits. Maximum genotypic coefficient of variation (GCV) and phenotypic coefficient of variation (PCV) was recorded for number of secondary branches per plant (24.95 and 26.16) followed by seed yield per plant (22.06 and 23.63). These results were well supported by similar findings by Kumar et al. (2007). Singh et al. (2011) and Kumar et al. (2013) reported high values for PCV and GCV for the number of secondary branches per plant and for seed yield per plant. The high values of genotypic coefficient of variation $(\mathrm{GCV})$ and phenotypic coefficient of variation (PCV) for these traits suggested the possibility of yield improvement through selection of these traits.

Maximum heritability (broad sense) was observed for plant height (96.79) followed by number of siliquae per main branch (91.49), number of secondary branches per plant (90.96) and days to 50\% flowering (88.42) and seed yield per plant (87.19). In a cross of Indian mustard, high estimates of heritability was reported for primary branches (Chaudhry and Sharma, 1982) High magnitude of heritability and moderate genetic advance for days to $50 \%$ flowering was earlier reported by Singh et al. (2011) which indicated that improvement in this trait could be done through selection feasible. High estimates of heritability coupled with high genetic advance as per cent of mean was observed for number of siliquae per main branch (91.49 and 21.40) followed by number of secondary branches per plant (90.96 and 49.02), days to $50 \%$ flowering (88.42 and 10.73) seed yield per plant (87.19 and 42.44) and number of primary branches per plant (80.76 and 39.08). Genetic advance as percentage of mean was highest for seed yield per plant, followed by plant height and number of branches as reported by (Beena et al. 1998; Gupta and Singh 1998; Singh et al. 1999 and Mondal and Khajuria, 2000). Mahla et al. (2003) also observed high estimates of heritability coupled with high genetic advance for seed yield per plant, number of siliqua on main branch and number of branches per plant. The above results were also well supported by similar findings by Kumar et al. (2007) who reported high heritability along with high genetic advance for days to $50 \%$ flowering and number of secondary branches per plant. Mahamood et al. (2003) also reported high heritability and corresponding genetic advance values for number of siliquas per plant, seed yield per plant and plant height in some Brassica juncea crosses. Lodhi et al. (2014) reported high heritability in conjunction with high genetic advance were observed for seed yield/ plant, number of secondary branches/ plant, 1000- seed weight, number of seeds/ siliqua, primary branch angle, number of primary branches/ plant, siliqua angle, siliquae on main shoot, and siliqua length suggesting predominant role of additive gene action for expression of these traits. The characters that show high heritability 
with high genetic advance are controlled by additive gene action (Panse and Sukhatme, 1967), can be improved through simple or progeny selection methods. The character showing high heritability along with low genetic advance can be improved by intermating superior genotypes of segregating population developed from combination breeding.

\section{Acknowledgement}

The Authors are sincerely grateful to the Hon'ble Vice-Chancellor, Sam Higginbottom Institute of Agriculture, Technology and Sciences, Allahabad, for providing the necessary facilities for completing the research work.

\section{References}

[1]. P Singh, Studies on genetic variability and diversity of rice. Madras Agric. J. 70(7), 1983, 436-440.

[2]. O. Kempthorne, An introduction to genetic statistics, (John Willy and Sons. Inc. New York, Pp.545. 1957).

[3]. V. G. Panse, and P. V. Sukhatme, Statistical method for agricultural workers (2nd Ed. ICAR, New Delhi: 381. 1967).

[4]. G. W. Burton, Quantitative inheritance of grasses. Proc. 6th Internatinal, Grassland Congress, 17-23 August, Pennsylvania State College, Pennsylvania, USA, 1952, (1) 277-283.

[5]. G. W. Burton, and E. H. De Vane, Estimating heritability in all fescue (Festuca arundinacea) from replicated clonal material. Agron. J. $45,1953,478-481$.

[6]. H. W. Johnson, H. F. Robinson and R. E. Comstock, Estimates of genetic and environmental variability in Soybean. Agron. J. 47: 1955, 314-318.

[7]. S. Kumar and M N. Misra, Study on genetic variability, heritability and genetic advance in populations in I n d i a $\mathrm{n}$ m stard [ Brassica juncea L. C z e r n \& C o s s.]. International Journal of Plant Sciences 2(1), $2007,188-190$.

[8]. B. Singh, Character association and path analysis under dryland condition in Indian mustard (Brassica juncea L.). Cruciferae Newsletter 25, 2004,99-100.

[9]. M. Singh, A. Tomar, C. N. Mishra, and S.B.L. Srivastava, Genetic parameters and character association studies in Indian mustard. Journal of Oilseed Brassica, 2(1) 2011, 35-38.

[10]. B. Kumar, A. Pandey and S.K. Singh, Genetic Diversity For Agro-Morphological and Oil Quality Traits In Indian Mustard (Brassica juncea L. Czern \& Coss). The Bioscan 8 (3) 2013, 771-775.

[11]. Chaudhry and Sharma, Note on the inheritance of some quantitative characters in a cross of Indian mustard. Indian Journal of Agri. Sci. $52,1982,23-25$.

[12]. P. Beena, V.B. Dawande, H.B. Kumbhalkar and V.P. Titare, Variability studies in mustard. Indian Journal of Soils and Crops, 8 1998, 219-220.

[13]. T.R. Gupta and I.J. Singh, Estimates of variability, correlations and co-heritability in Toria. J. Maharashtra Agric. Univ., 23(1), 1998, 4546.

[14]. A.P. Singh, T.P. Kumber, N.K. Yadava, and S.D. Batra, Genetic components of seed yield, yield attributes and oil content in toria, Cruciferae News letter. 21, 1999, 103-104.

[15]. S.K. Mondal and M.R. Khajuria, Genetic analysis of yield attributes in mustard. Environ. Ecology 18(1), 2000, 1-5.

[16]. Mahla, H. R., Jambhulkar, S. J., Yadav, D. K. and Sharma, RGenetic variability, correlation and path analysis in Indian mustard (Brassica juncea (L.) Czern and Coss.). The Indian Journal of Genetics and Plant Breeding. 63 (2), 2003,171-172.

[17]. M. Kumar, T.S. Singh and V. Kumar, Genetic variability, heritability, genetic advance and character association in Indian mustard (Brassica juncea L. czern and Coss) grown in semi- alkali soils. J. of Farming Systems Rese and Development, 13 (3) 2007, 284-287.

[18]. T. Mahamood, A. Muhammad, S. Iqbal, and M. Anwar, Genetic variability and heritability estimates in summer mustard (Brassica juncea L.). Asian Journal of Plant Science 2(1),2003, 77-79.

[19]. B, Lodhi, N.K Thakral, R. Avtar and A. Singh, Genetic variability, association and path analysis in Indian mustard (Brassica juncea), Journal of oilseed Brassica 5(1),2014,26-31.

Table 1. Analysis of variance for 9 quantitative characters in crosses of Indian mustard (Brassica juncea L.)

\begin{tabular}{|c|l|c|c|c|}
\hline \multirow{2}{*}{ S.N. } & \multirow{2}{*}{ Characters } & \multicolumn{3}{|c|}{ Mean Sum of Square } \\
\cline { 3 - 5 } & Days to $50 \%$ flowering & $\begin{array}{c}\text { Replications } \\
\mathrm{df}=1\end{array}$ & $\begin{array}{c}\text { Hybrids } \\
\mathrm{df}=47\end{array}$ & $\begin{array}{c}\text { Error } \\
\mathrm{df}=47\end{array}$ \\
\hline 1. & 0.87 & $27.54^{* *}$ & 2.70 \\
\hline 2. & Plant height & 3.64 & $209.24^{* *}$ & 2.96 \\
\hline 3. & Siliquae per main branch & $11.18^{*}$ & $41.73^{* *}$ & 2.10 \\
\hline 4. & Primary branches per plant & 1.95 & $5.48^{* *}$ & 2.10 \\
\hline 5. & Secondary branch per plant & & & \\
\hline
\end{tabular}




\begin{tabular}{|c|l|c|c|c|}
\hline & & 2.79 & $33.47^{* *}$ & 1.63 \\
\hline 6. & Length of Siliquae & 2.79 & 0.26 & 0.15 \\
\hline 7. & Number of seeds per siliquae & $10.46^{* *}$ & $5.98^{* *}$ & 1.14 \\
\hline 8. & Days to maturity & $10.69^{* *}$ & $7.11^{* *}$ & 1.45 \\
\hline 9. & Seed yield per plant & $16.10^{* *}$ & $15.67^{* *}$ & 0.98 \\
\hline
\end{tabular}

** and * significant at 0.01 and 0.05 level of significance, $\mathrm{df}=$ degrees of freedom.

Table 2. Estimates of mean, range, variance components, coefficients of variability, heritability and genetic advance as percentage of mean for 9 quantitative characters in Indian mustard (Brassica juncea L.)

\begin{tabular}{|c|c|c|c|c|c|c|c|c|c|c|c|c|}
\hline \multirow[t]{2}{*}{ S.N. } & \multirow[t]{2}{*}{ Characters } & \multirow{2}{*}{ Mean } & \multirow{2}{*}{$\mathbf{S E} \pm$} & \multicolumn{2}{|c|}{ Range } & \multirow{2}{*}{$\sigma^{2} \mathbf{g}$} & \multirow{2}{*}{$\sigma^{2} p$} & \multirow{2}{*}{$\begin{array}{l}\text { GCV } \\
(\%)\end{array}$} & \multirow{2}{*}{$\begin{array}{r}\text { PCV } \\
(\%) \\
\end{array}$} & \multirow{2}{*}{$h^{2}($ b.s) $\%$} & \multirow{2}{*}{ GA } & \multirow{2}{*}{$\begin{array}{l}\text { GAM } \\
(5 \%)\end{array}$} \\
\hline & & & & Min. & Max. & & & & & & & \\
\hline 1. & $\begin{array}{l}\text { Days to } 50 \% \\
\text { flowering }\end{array}$ & 65.79 & 2.35 & 59.00 & 73.50 & 13.74 & 15.54 & 5.54 & 5.89 & 88.42 & 7.18 & 10.73 \\
\hline 2. & Plant height & 165.52 & 3.10 & 143.40 & 196.75 & 100.88 & 104.23 & 6.01 & 6.10 & 96.79 & 20.35 & 12.18 \\
\hline 3. & $\begin{array}{l}\text { Number of } \\
\text { siliquae per main } \\
\text { branch }\end{array}$ & 41.00 & 2.61 & 29.30 & 53.20 & 20.59 & 22.51 & 10.86 & 11.35 & 91.49 & 8.94 & 21.40 \\
\hline 4. & $\begin{array}{l}\text { Primary } \\
\text { branches per } \\
\text { plant }\end{array}$ & 7.13 & 1.34 & 5.20 & 11.75 & 2.41 & 2.98 & 21.11 & 23.49 & 80.76 & 2.87 & 39.08 \\
\hline 5. & $\begin{array}{l}\text { Secondary } \\
\text { branches per } \\
\text { plant }\end{array}$ & 15.25 & 2.30 & 7.15 & 32.45 & 15.61 & 17.16 & 24.95 & 26.16 & 90.96 & 7.76 & 49.02 \\
\hline 6. & $\begin{array}{l}\text { Length of } \\
\text { siliquae }\end{array}$ & 5.25 & 0.71 & 4.45 & 6.10 & 0.05 & 0.21 & 4.25 & 8.75 & 23.68 & 0.22 & 4.27 \\
\hline 7. & $\begin{array}{l}\text { Number of seeds } \\
\text { per siliquae }\end{array}$ & 14.37 & 1.93 & 10.00 & 19.00 & 2.29 & 3.61 & 10.24 & 12.85 & 63.55 & 2.48 & 16.82 \\
\hline 8. & Days to maturity & 114.71 & 2.17 & 108.00 & 117.50 & 2.72 & 4.34 & 1.44 & 1.82 & 62.80 & 2.69 & 2.35 \\
\hline 9. & $\begin{array}{l}\text { Seed yield per } \\
\text { plant }\end{array}$ & 12.57 & 1.79 & 6.80 & 25.30 & 7.96 & 4.34 & 22.06 & 23.63 & 87.19 & 5.42 & 42.44 \\
\hline
\end{tabular}

Where: SE \pm Standard error, Min $=$ Minimum, Max=Maximum, $\sigma^{2} g=$ Genotypic variance, $\sigma^{2} p=$ Phenotypic variance, GCV percentage $=$ Genotypic coefficient of variation, $\mathrm{PCV}$ percentage $=$ Phenotypic coefficient of variation, $\mathrm{h}^{2}(\mathrm{bs})=$ heritability in broad sense, $\mathrm{GA}=$ genetic advance, GAM=Genetic advance as percent of mean at $5 \%$. 